SHS Web of Conferences 2, 00023 (2012)

DOI: $10.1051 /$ shsconf $/ 20120200023$

(C) Owned by the authors, published by EDP Sciences, 2012

\title{
Community work - the missing link of municipal social policy
}

\author{
M. Moors
}

Riga Stradiņš University, Latvia

\begin{abstract}
Municipal social policy has an important role in dealing with social problems of citizens. On micro level, municipalities spend a substantial amount of their budget solving such problems. However, increasing the amount of money spent on solving problems of each individual at micro level does not provide efficient fulfilment of the tasks defined for municipal social policy making. Thus new, complementary solutions should be looked into, as new ways of development of social work in municipalities should be designed with the aim to increase the level of citizen participation and joint responsibility, especially of socially vulnerable groups. Research results let the author conclude that social activity of socially vulnerable groups should be promoted by creating a series of prerequisites, among which citizen participation, need for organisational support, activities that would foster politician and municipality officials' attitude towards citizen participation and their social capital increase, two-way relationship between citizens and officials, and the worker that would promote citizen participation, among which is social policy making, are considered to be very important. All of this can be successfully reached by developing community work in local municipalities. This is the missing link to combine macro and micro levels, or political determination and practical implementation of citizen participation.
\end{abstract}

Key words: municipal social policy, citizen participation, joint responsibility, citizen participation prerequisites, community work

After regaining its independence in 1990's, Latvian society experienced substantial social and policy changes. Inhabitants were granted various types of rights and freedoms that had been restricted prior to the event; however, different social problems were brought along-decline in gross domestic product (GPD), unemployment, decrease in purchasing power and deterioration of living standards, banking crisis, depopulation (Rajevska, 2006; 8-9), etc. The existing conditions demanded establishment of adequate social security system that would correspond the new social reality.

One of the most important factors of social policy development was the reform of social service system, completed in 2003. The newly approved Social Service and Social Assistance Act, which came into force on January 1, 2003, aimed towards further decentralisation by delegating a series of tasks to local governments: responsibility for municipalities to create social service departments, granting social assistance availability by defining citizen participation obligations, provision of social services only after assessment of client's needs, granting social service provision close to the place of residence, legitimisation of professional social work at micro level, defining responsibilities and objectives of social welfare workers.

According to the law "On local governments" and Social Service and Social Assistance Act (Law "On local governments", article 15 (1; 7); Social Service and Social Assistance Act, article 9 (1)), in Latvia local municipalities have been imposed obligations and competences in social policy implementation. Municipalities are responsible for ensuring social service and social assistance accessibility for every citizen in the particular municipality (in exceptional cases - to citizens of other municipalities). As defined by legislation on social services and social assistance, municipalities have unlimited opportunities in social sphere to the extent not in conflict with the Constitution or democratic principles of governance (Pūķis, 2010; 43), if the municipality has met the obligations of providing those social assistance forms stated by the government. Thus, the discussion of a municipality's social policy

This is an Open Access article distributed under the terms of the Creative Commons Attribution License 2.0, which permits unrestricted use, distribution, and reproduction in any medium, provided the original work is properly cited. 


\section{SHS Web of Conferences}

within the limits defined by the State - specific tools and events aimed at providing necessary assistance to citizens living in a designated area (municipality) - is justifiable.

\section{Municipal policy development: Riga sample}

Riga municipality is characterised by the fact that it is the largest municipality by population; $1 / 3$ of the inhabitants of Latvia live there. This defines the specific tasks of the municipality as well as the possibilities of dealing with social issues in it - a substantial amount of its budget is spent on permanent function of the city of Riga - to provide social services and social assistance according to citizen needs. Riga has been a multifold pioneer in the development of social policy: in 1996 individual social work with a case was started by professional social workers for work with families with children, in late 1990's municipality could boast with social service purchasing practice; currently Riga possesses the largest range of social services provided for citizens in a municipality.

According to statistics, a recognizable amount of its social budget in Riga is spent on individual social assistance and social services. If in 2000 social service system received $6.46 \%$ (Sociāā palīdzība Rīgā 2000. gadā, 2001; 8), in 2004-7.89\% (Sociālā sistēma Rīgā 2004. gadā, 2005; 8), then in 2008 the share is $8 \%$ (Rīgas domes Labklājības departamenta Gadagrāmata "Sociālā sistēma un veselības aprūpe Rīgā 2008. gadā", 2009; 10), but in 2010-8.02\% (Rīgas domes Labklājības departamenta Gadagrāmata "Sociālā sistēma un veselības aprūpe Rīgā 2010. gadā”, 2011;12) of Riga City budget funds. Thus, a particular trend can be observed in shares of the Riga City budget funds. Due to socioeconomic downturn, which started in the second half of 2008, a rapid growth of the inhabitants seeking social services has been observed. In 2008 there were 17,758 registered poor persons in Riga, but in $2009-28,898$ poor persons, then in 2010 there were 44,275 poor persons (the number has risen by $53 \%$ compared to 2009); the number of beneficiaries of social benefits among all citizens of Riga City in 2008 and 2009 was $8.6 \%$; however, in 2010 the number rose to $10.2 \%$ of the number of inhabitants living in the City of Riga (Rīgas domes Labklājības departamenta Gadagrāmata "Sociālā sistēma un veselības aprūpe Rīgā 2010. gadā”, 2011; 15-17).

Still, several problems in municipal social policy must be stated.

Firstly, maintenance of social policy operation should be referred to. Despite the fact that Riga municipality spends a substantial amount of its funds on social service and social assistance provision to its citizens, dissatisfaction with municipal operations in social sphere has been observed (Rìgas domes darbības vērtējums: Rīgas iedzīvotāju aptauja, 2010; 19-20; Rīgas domes darbības vērtējums: Rīgas iedzīvotāju aptauja, 2009; 19-20).

Secondly, many other municipalities of Latvia experience difficulties to pay the benefit as stated by the government to ensure minimum income level to its citizens (Insiders' views about Social Inclusion and Social Security in Latvia, 2006). This leads to a conclusion that municipalities must seek other resources to help its inhabitants, respectively, the resources must be searched within community.

Thirdly, despite the efforts to create and improve services, a recognizable amount of individuals reject the role of social service consumer. This can be observed in unwillingness to acquire new knowledge, not wanting to change, rejecting the possibility to be healthy, living without a permanent place of living etc. In order not to leave this part of society unmonitored and avoid widespread asocial behaviour and deviance, new support measures are introduced-benefits and services that not always prove efficient. Such activities may result in creating the environment that promotes individuals' dependence on social assistance and its service system, but does not enforce citizen self abilities to solve their problems or difficulties. At the same time municipality remains the largest social service contractor. However, there is no real competition among social service providers. Thus, these providers are financially dependant on the municipality, but municipality funds for developing social services are quite restricted.

Fourthly, social policy programmes, despite all the costs they demand, not always prove effective and in some cases even result opposite to the expected. The growing number of homeless people among the able-bodied may serve as a great example for this (Kamerovska, Moors, 2009). 


\section{Int. Conf. SOCIETY. HEALTH. WELFARE; Congr. of Rehabilitation Doctors of Latvia}

The above mentioned lets us conclude that by only increasing funds for individual problem solution at micro level it is impossible to find solutions to those tasks that are imposed to municipalities in social policy sphere. New and existing situation improving solutions for social policy development in municipality should be discovered, the main aim of which has to be citizen, especially socially vulnerable group, participation and joint responsibility increase when dealing with personal and social issues with the help of municipal social system support.

\section{Socially vulnerable citizen participation and joint responsibility}

Within the process of receiving individual social services and social assistance a client should be ready for collaboration, thus legislation has defined regulations of individual's co-responsibility. Nevertheless, such important resources as citizen between social ties and the ability to rejoin for self-assistance have been somewhat neglected in Latvia.

Analysing prerequisites of a quality life for each individual Talis Tisenkopfs highlights the importance of human capacity -individual's autonomy, freedom, abilities, knowledge and practical skills that would allow them to form an appropriate life and self-actualisation model (Tisenkopfs, 2006; 13, 19). Implementing Talis Tisenkopfs' proposed concept, the ability to take initiative, realisation of one's knowledge and practical skills in social context can be defined as social capacity. According to its context, this term can be approximate to the term social engagement, especially when stressing the contextual importance of the latter within active citizen self initiative and social capacity context. Social engagement characterises inhabitants as active citizens and social action members or along doers rather than social service receivers and users. Thus, social engagement and participation fosters citizen social ownership.

Municipal social policy must be aimed at situation improvement of socially vulnerable groups. According to the terminology employed by sociologist Anthony Giddens, socially vulnerable groups must be connected with understanding the concept of "agents". This concept is directly linked with power implementation of one or another form. Whatever the agent, it must possess the ability to intervene in the events, influence a process, which also includes power implementation over others (Giddens, 1984, 1985, 1986; 14-15). The agent needs power so he can influence others, thus achieving the expected results and reaching one's aims. In social work theory the approach is known as empowerment approach (Lee, 2001; 52), which is the basis of community work. The empowerment approach is aimed at revealing yet undiscovered resources by a person themselves highlighting the possibilities of particular lives and helping to accomplish them.

\section{Research: Community work and municipal social policy development}

Community work is aimed at promoting citizen participation; the intervention is carried out at a local level by voluntary and active engagement of the involved groups (Sedvalde, 2005; 28). Consequently, community work may prove effective only if the members of a community themselves take primary responsibility for their actions as such.

Greater citizen involvement promotes collaborative culture that not only requires citizen participation, but also fosters its development. Working on community issues creates the sense of ownership over the happenings thus creating a democratic community life (Morse, 2004; 124). "Sense of ownership" is the major factor of the existence of social joint responsibility. No long-term process is possible while there is no sense of ownership and responsibility for the future of the community in the level beyond a common person (Ibid; 185). Community work is based upon people's critical consciousness of their status, social situation and critical assessment of their knowledge - both existing and the required one. Via group ties and collective action people's power potential and ability to affect social processes are increased.

To be able to define participation potential of socially vulnerable groups, set required prerequisites and the role of community work in municipal policy making, the author of the article 


\section{SHS Web of Conferences}

conducted a research within his Thesis. The study was carried out in two parts between 2008 and 2010 .

Methodology of the study: partly structured in-depth interviews with social policy experts and faceto-face interviews with 502 Riga City social service and social assistance receivers. The main research question was: what is the desire and willingness of the socially disadvantaged residents to participate in addressing social problems of their peers and themselves and improving the social situation in Riga municipality? The results of the research have been presented in various scientific conferences (Moors, 2008; 57; Moors, Švekle, 2010; 407).

\section{Major conclusions of the research}

It must be admitted that the respondents possess low social ownership level as they do not believe in their power to affect decisions made in their local municipality, they choose individual participation ways in problem solving, but avoid taking part in group activities with rational aims behind them. In accordance with theoretical basis of social work, increase in citizen participation can be obtained by delegating more power to socially vulnerable groups over their own life conditions. However, citizens, including socially vulnerable groups, do not tend to become active when their social interests and needs should be defended; thus they avoid taking part in activities that can be understood with the concept of "citizen participation".

Social policy-makers' expectations are aimed at citizens with high level of organisation, e.i., professionally prepared ambitious and naturally active cooperation partners. Nevertheless, this kind of orientation is in conflict with the opinion of experts themselves, inhabitants, and with conclusions drawn from literary studies of the subject on small social capital among socially vulnerable groups, active participation deficit and lack of knowledge.

Citizen participation includes active participation dimension and defined rational attitude that contrasts indifference. Thus, citizen participation is known as common activities of several people or several groups that are characterised by active contribution. This requires a certain list of prerequisites that have also been highlighted in the author's theoretical and empirical study:

1) access to information, which ensures effective information exchange between citizen union and local municipality representatives;

2) feedback on the proposals and their effect on decisions made;

3) regularity in communication and dialogue with inhabitants;

4) financial and human resources;

5) paid employee for regular and flexible planning and work coordination;

6) permanent space for planning community activities;

7) mobilisation of socially vulnerable groups for participation activities;

8) emphasis of existing issues within the community;

9) citizen participation mechanisms-both in form of laws and regulations and informal "regulations" or traditions;

10) leaders among citizens;

11) respectable attitude towards citizen participation from politicians and municipality officials;

12) knowledge and skills of citizens and municipality officials on forms of citizen participation, procedures and possibilities.

Research results also indicated that citizen social engagement and participation in municipal social policy has been insufficient. Thus, "a black hole" between social policy aims - to foster socially vulnerable group participation and social responsibility - and their implementation in practice exists. Consequently, it can be detected that an instrument that would promote citizen participation and social responsibility in social policy implementation is needed. 
Int. Conf. SOCIETY. HEALTH. WELFARE; Congr. of Rehabilitation Doctors of Latvia

Conclusions drawn in the empirical part of the study justify the statement that citizen participation of socially vulnerable groups has to be raised compared to the existing activity observed. Survey result analysis indicates on a very low level of citizen social activity, among which negative assessment rate is considerably higher than the positive one, which leads to the conclusion that citizen participation increase in very important among socially vulnerable group members. To reach this, certain prerequisites should be observed that include creation of mechanisms that promote citizen participation, necessity of organisational support, activities that aim at attitude formation of politicians and municipality officials towards citizen participation activities and social capital increase among citizens, two-way relationships between citizens and municipality officials, and a worker that would foster inhabitants to participate in various activities that also include social policy making. These prerequisites can be successfully implemented if community work is developed within local municipalities.

Analysing citizen participation and social activity in Riga case, it must be concluded that the missing link is the direct action or intervention at operational level, e.i., direct interaction between professionals and clients takes place. At this level the issues form being political turn into being personal (Jamrozik, 1998 (repr. 2000); 48). Activities at this level are mainly connected with social work, as this profession has a central role in shaping society's formal reaction on social problems (Ibid; 39). This is the missing link to reconnect macro and micro levels, or in other words, political determination with realistic implementation of citizen participation. Thus, a structure that makes citizen social activity necessity a personal and private problem is required. Such mechanism is offered by community work. At operational level, a paid employee is needed with the task to organise community work and focus on issues of social engagement.

\section{References}

[1] Giddens, A. The Constitution of Society: Outline of the Theory of Structuration. California: California Press, 1984, 1985, 1986.

[2] Insiders' views about Social Inclusion and Social Security in Latvia. Project Poverty, social assistance and social inclusion-Developments in Estonia and Latvia in a comparative perspective. http://www.politika.lv/en/topics/social_integration/16409/

[3] Jamrozik, A. The sociology of social problems: theoretical perspectives and methods of intervention. Cambridge: Cambridge University Press, 1998 (repr. 2000).

[4] Kamerovska, D., Moors, M. Arī ar "ragaviņām" uz patversmi: sociālais darbs ar bezpajumtniekiem. Sociālais darbinieks, 2009, 30 (1).

[5] Lee, Judith A.B. The Empowerment Approach to Social Work Practice: Building the Beloved Community. New York: Columbia University Press, 2001. Questia. http://www . questia. com/PM. qst?a=o\&d=100248977

[6] Likums "Par pašvaldībām". Latvijas Vēstnesis, Nr. 61 (192), 24.05.1994.

[7] Sociālo pakalpojumu un sociālās palīdzības likums. Latvijas Vèstnesis, Nr.168 (2743), 19.11.2002.

[8] Moors, M. Iedzīvotāju līdzdalība pašvaldības sociālās politikas veidošanā-ekspertu vērtējums. 2. starptautiskā starpdisciplinārā zinātniskā konference Sabiedrība, veselība, labklājība (Rīga, 2008. gada 6.-7. novembris): Tēzes. Rīga: RSU, 2008.

[9] Moors, M., Švekle, I. Klientu gatavība līdzdalībai pašvaldības sociālās politikas veidošanā. Rīgas Stradiņa universitāte 2010. gada zinātniskās konferences tēzes (Rīga, 2010. gada 18.-19. marts). Rīga: RSU, 2010.

[10] Morse, Suzanne W. Smart communities: how citizens and local leaders can use strategic thinking to build a brighter future. San Francisco: Jossey-Bass, 2004.

[11] Pūķis, M. Pašu valdība: Latvijas pašvaldību pieredze, idejas un nākotnes redzējums. Rīga: Latvijas Pašvaldību savienība, 2010. 


\section{SHS Web of Conferences}

[12] Rajevska, F. Sociālās politikas attīstība Latvijā-iekšējo un ārējo faktoru mijiedarbības iznākums. Rakstu krājums: Sociālā atstumtība un sociālā iekļaǔ̌ana: situācijas izvērtējums Latvijā. Rīga: LU Akadēmiskais apgāds, 2006.

[13] Rīgas domes Labklājības departamenta Gadagrāmata "Sociālā sistēma un veselības aprūpe Rīgā 2008. gadā”. Rīga, 2009.

[14] Rīgas domes Labklājības departamenta Gadagrāmata "Sociālā sistēma un veselības aprūpe Rīgā 2010. gadā”. Rīga, 2011.

[15] Sociālā palīdzība Rīgā 2000. gadā. Rīga, 2001.

[16] Sociālā sistēma Rīgā 2004: Gadagrāmata. Rīgas, 2005.

[17] Sedvalde, E. Kopienas darbs kā sociālā darba metode ar personu grupām un sabiedrību. Dzīves jautājumi X. Rīga: Sociālā darba un sociālās pedagoǵijas augstskola “Attīstība”, 2005.

[18] Tisenkopfs, T. Ko nozīmē laba dzīve mūsdienu Latvijā? Dž̄ves kvalitāte Latvijā. Rīga: Zinātne, 2006. 